\title{
Peran Budaya Organisasional Memoderasi, Pengaruh Supervisi Kepala Sekolah dan Motivasi Kerja terhadap Kinerja Guru SMK Negeri Wilayah Timur Pemalang
}

\author{
Dyah Novie Riyanti \\ Program Pasca Sarjana Universitas STIKUBANK Semarang \\ Email: dyahnovie11@gmail.com
}

\begin{abstract}
Article Info
\section{Abstract}

Article History

Received: 2020-11-17

Revised: 2021-01-05

Published: 2021-01-13

This study was investigated about the role of organizational culture moderated influence headmaster supervision and motivation on teacher performance. Specifically, this study to examine and analisys whether the role of organizational culture moderated influence headmaster supervision and motivation on teacher performance. The contribution of this study is explain and explore the previous research about the

Keywords:

Headmaster;

Supervision;

Motivation;

Organizational Culture;

Teacher Performance. influence organizational culture, headmaster supervision, and motivation on teacher performance, Population and study sample was a high school teacher District Regency Pemalang as much as 120 people. The research data is the primary data collected directly from the respondents to the questionnaire. The research method approach with computer software SPSS for Windows version 19. The method of data analysis using Moderation Regression analisys (MRA) type quasi moderator. The results showed organizational culture to weaken the effects of headmaster supervision on teacher performance, and the organizational culture does not moderate the effects of motivation on teacher performance.
\end{abstract}

\begin{tabular}{l}
\hline Artikel Info \\
\hline Sejarah Artikel \\
Diterima: $2020-11-17$ \\
Direvisi: 2021-01-05 \\
Dipublikasi: 2021-01-13
\end{tabular}

Kata kunci:

Supervisi;

Kepala sekolah;

Motivasi;

Budaya organisasional; Kinerja guru.

\begin{abstract}
Abstrak
Penelitian ini bertujuan untuk mengetahui peran budaya organisasional memoderasi pengaruh supervisi kepala sekolah dan motivasi terhadap kinerja guru. Tujuan spesifik penelitian ini adalah untuk menguji dan menganalisis apakah budaya organisasional berperan memoderasi pengaruh supervisi kepala sekolah dan motivasi terhadap kinerja guru. Kegunaan penelitian adalah menjelaskan dan memperluas penelitian sebelumnya mengenai pengaruh budaya organisasional, supervisi kepala sekolah dan motivasi terhadap kinerja guru. Populasi dan sampel penelitian adalah guru SMK Negeri Wilayah Timur Kabupaten Pemalang sebanyak 120 orang. Data penelitian adalah data primer yang diperoleh langsung dari responden dengan kuesioner. Metode penelitian menggunakan pendekatan computer software dengan program SPSS for Windows versi 19. Adapun metode analisis data menggunakan Moderation Regression Analisys (MRA) tipe quasi moderator. Hasil penelitian menunjukkan bahwa budaya organisasional memperlemah pengaruh supervisi kepala sekolah terhadap kinerja guru, serta budaya organisasi tidak memoderasi pengaruh motivasi terhadap kinerja guru.
\end{abstract}

\section{PENDAHULUAN}

Undang-undang Nomor 14 tahun 2005 tentang Guru dan Dosen pasal 1 ayat 1 menyatakan bahwa guru adalah pendidik profesional dengan tugas utama mendidik, mengajar, membimbing, mengarahkan, melatih, menilai, dan mengevaluasi peserta didik pada pendidikan anak usia dini jalur pendidikan formal, pendidikan dasar, dan pendidikan menengah, Dalam pelaksanaan fungsi dan tugasnya, guru sebagai profesi menyandang persyaratan tertentu sebagaimana tertuang di dalam Undang-Undang Republik Indonesia Nomor 20 tahun 2003 tentang Sistem Pendidikan Nasional. Dalam pasal 39 (1) dan (2) yang menyatakan bahwa: "Tenaga kependidikan bertugas melaksanakan administrasi, pengelolaan, pengembangan, pengawasan, dan pelayanan teknis untuk menunjang proses pendidikan pada satuan pendidikan. Pendidik merupakan tenaga profesional yang bertugas merencanakan dan pelaksanakan proses pembelajaran, menilai hasil pembelajaran, melakukan pembimbingan dan pelatihan, serta melakukan penelitian dan pengabdian kepada masyarakat, terutama bagi pendidik pada perguruan tinggi”.

Guru merupakan salah satu komponen dalam pengelolaan sekolah yang memiliki peran yang sangat strategis dalam upaya mengembangkan potensi peserta didik,dalam melaksanakan tugasnya guru harus memiliki target yang jelas untuk mencapai dan membentuk dasar dorongan untuk bekerja, diterapkan untuk jangka waktu tertentu. 
Tugas guru erat kaitannya dengan peningkatan sumber daya manusia melalui sektor pendidikan, oleh karena itu perlu upaya-upaya untuk meningkatkan mutu guru menjadi tenaga profesional,yaitu perlu memiliki sejumlah kemampuan atau kompetensi dan motivasi. Menurut Peraturan Menteri Pendidikan Nasional Republik Indonesia Nomor 16 Tahun 2007 yang dimaksud Kompetensi Profesional adalah menguasai materi pembelajaran secara luas dan mendalam yang memungkinkan dapat membimbing peserta didik sesuai standar nasional Indonesia.

Pembinaan kepada guru sebagai pendidik diperlukan untuk meningkatkan kinerjanya. Peningkatan kinerja berkenaan dengan kesesuaian antara harapan seseorang dengan imbalan yang disediakan. Pembinaan kepada guru berdampak pada prestasi kerja, yang diberikan kepada personel pendidikan, untuk mengembangkan proses pendidikan yang lebih baik". Dari kutipan tersebut dapat dijabarkan bahwa dengan adanya pelaksanaan supervisi oleh kepala sekolah diharapkan bisa memberi dampak terhadap terbentuknya sikap profesional guru. Serangkaian usaha pemberian bantuan kepada guru dalam bentuk layanan professional yang diberikan oleh supervisor (pengawas sekolah, kepala sekolah, dan pembina lainya) guna meningkatkan mutu proses dan hasil belajar mengajar, karena supervisi atau pembinaan guru tersebut lebih menekankan pada pembinaan guru, upaya memperbaiki dan meningkatkan kemampuan professional guru. Makawimbang (2011).

Dalam Kamus Besar Bahasa Indonesia (Depdikbud 1990) kinerja berarti sesuatu yang dicapai, prestasi diperlihatkan atau kemampuan kerja. Dalam sebuah artikel yang diterbitkan oleh lembaga administrasi negara (1992) merumuskan kinerja merupakan terjemahan bebas dari istilah Performance yang artinya adalah prestasi kerja atau pelaksanaan kerja atau pencapaian kerja atau hasil kerja. Menurut Mangkukerta (2008) kinerja merupakan hasil secara dan kuantitas yang dicapai seseorang pegawai dalam melaksanakan tugasnya sesuai dengan tanggung jawab yang diberikan kepadanya.Sedangkan menurut Hadari ( 2001) menyatakan bahwa kinerja adalah hasil dari pelaksanaan suatu pekerjaan, baik yang bersifat fisik/mental maupun non fisik/non mental.

Dalam Permendiknas nomor 41 tahun 2007 tanggal 23 November 2007 tentang Standar Proses untuk Satuan Pendidikan Dasar dan Menengah menyatakan bahwa kinerja guru merupakan pemberian keteladanan, membangun kemauan, dan mengembangkan potensi serta kreatifitas peserta didik pada proses pembelajaran setiap satuan pendidikan Dasar dan Menengah yang interaktif, inspiratif, menyenangkan, menantang, dan memotivasi peserta didik sesuai dengan Standar Nasional Pendidikan melalui standar proses pembelajaran.

\section{a. Kinerja Guru}

Dalam Kamus Besar Bahasa Indonesia (Depdikbud 1990) kinerja berarti sesuatu yang dicapai, prestasi diperlihatkan atau kemampuan kerja. Dalam sebuah artikel yang diterbitkan oleh lembaga administrasi negara (1992) merumuskan kinerja merupakan terjemahan bebas dari istilah Performance yang artinya adalah prestasi kerja atau pelaksanaan kerja atau pencapaian kerja atau hasil kerja.

Menurut Mangkukerta (2008) kinerja merupakan hasil secara dan kuantitas yang dicapai seseorang pegawai dalam melaksanakan tugasnya sesuai dengan tanggung jawab yang diberikan kepadanya.Sedangkan menurut Hadari ( 2001) bahwa kinerja adalah hasil dari pelaksanaan suatu pekerjaan, baik yang bersifat fisik/mental maupun non fisik/non mental.

Dalam Permendikans nomor 41 tahun 2007 tanggal 23 November 2007 tentang Standar Proses untuk Satuan Pendidikan Dasar dan Menengah menyatakan bahwa kinerja guru merupakan pemberian keteladanan, membangun kemauan, dan mengembangkan potensi serta kreatifitas peserta didik pada proses pembelajaran setiap satuan pendidikan Dasar dan Menengah yang interaktif, inspiratif, menyenangkan, menantang, dan memotivasi peserta didik sesuai dengan Standar Nasional Pendidikan melalui standar proses pembelajaran. Dimensi tugas utama guru dalam permendiknas Nomor 41 tahun 2013 adalah: (1) perencanaan pembelajaran, (2) pelaksanaan proses pembelajaran yang aktif dan efektif,(3) penilaian hasil pembelajaran

Henry Simamora (1995) mengatakan Kinerja adalah tingkt hasil kerja karyawan dalam mencapai persyaratan - persyaratan pekerjaan yang diberikan, sedangkan Gibson (1998) mengatakan kinerja adalah hasil yang diinginkan dari perilaku. Adapun Miner (1998) mengatakan kinerja adalah tingkat keberhasilan seorang karyawan di dalam melaksanakan tugasnya. Kinerja didefinisikan sebagai tingkat kebutuhan seorang individu sebagai pengharapan atas pekerjaan yang telah dilakukan. Setiap harapan dari individu dinilai berdasrkan peran.jika peran yang dimainkan seorang individu tidak diketahui dengan jelas atau Nampak samar, maka tiap individu tidak akan mengtahui secara persis apa yang diharapkan.Kinerja juga merupakan hasil yang telh dicapai seseorang yang berhubungan dengan tugas dan peran yang dilakukannya. Kinerja mencakup segi usaha, loyalitas,

Hasil Penilaian Kinerja Guru (PKG) merupakan dasar untuk menghitung angka kredit yang diperoleh guru atas kinerja pembelajaran yang dilakukannya pada tahun tersebut, sebagai bagian dalam proses pengembanagan karir dan promosi guru untuk kenaikan pangkat dan jabatan fungsional guru 


\section{b. Fungsi Kepala Sekolah Sebagai Supervisor Pengajaran}

Kepala sekolah sebagai seorang supervisor, mempunyai kompetensi yang harus dimiliki berdasarkan permendiknas nomor 13 tahun 2007 adalah :

1) Merencanakan program supervisi akademik dalam rangka meningkatkan profesionalisme guru;

2) Melaksanakan supervisi akademik terhadap guru dengan menggunakan pendekatan teknik supervisi yang tepat;

3) Menindaklanjuti hasil supervisi akademik terhadap guru dalam rangka meningkatkan profesionalisme guru.

Keputusan Menteri Pendidikan dan Kebudayaan No.0296 tahun 1996 dalam Daryanto (2013) Kepala sekolah adalah guru yang memperoleh tambahan tugas untuk memimpin penyelenggaraan pendidikan dan upaya peningkatan mutu pendidikan, Kepala sekolah juga sebagai pemimpin dalam dalam mengambil kebijakan, sehingga dapat memfokuskan pada upaya bagaimana kinerja gurulebih baik agar dapat mencapai hasil belajar yang optimal disetiap elulusan.Pemikiran mengenai peran dan kapabilitas (kemampuan) seperti ini dapat terelisasi maka setiap komponen dalam pendidikan juga harus saling bekerja sama sehingga secara tidak langsung semua pihak dapat mendukung peran, tanggung jawab dan kinerja kepala sekolah dalam memimpin proses pembelajaran.

Menurut Gwynn, dalam Bafadal (2004), teknik supervisi digolongkan menjadi dua kelompok, yaitu teknik perorangan dan teknik kelompok. Teknik supervisi individual meliputi : 1) kunjungan kelas, 2) percakapan pribadi, 3) kunjungan antarkelas, 4) penilaian sendiri. Sedang teknik supervisi kelompok meliputi : 1) kepanitiaan, 2) kursus, 3) laboratorium kelompok, 4) bacaan terpimpin, 5) demonstrasi pembelajaran, 6) perjalanan staf, 7) diskusi panel, 8) perpustakaan profesional, 9) organisasi profesional, 10) bulletin supervisi, 11) sertifikasi guru, 12) tugas belajar, 13) pertemuan guru.

Dari beberapa pendapat dan uraian tersebut diatas dapat diambil kesimpulan, bahwa supervisi kepala sekolah adalah proses pembinaan kepala sekolah kepada guru dalam rangka memperbaiki proses belajar mengajar. Adapun teknik yang biasa digunakan adalah kunjungan kelas, pertemuan baik formal maupun informal serta melibatkan guru lain yang dianggap berhasil dalam proses belajar mengajar. Ada beberapa teknik yang biasa digunakan kepala sekolah dalam mensupervisi gurunya, namun dalam penelitian ini hanya indikator : kunjungan kelas, semangat kerja guru, pemahaman tentang kurikulum, pengembangan metode dan evaluasi, rapat-rapat pembinaan, dan kegiatan rutin diluar mengajar yang kami teliti sedangkan indikator lain tidak kami teliti karena kurang mengungkap masalah yang kami teliti.

\section{c. Penilaian Kinerja Guru}

Dalam Pedoman Pelaksanaan Penilaian Kinerja Guru (PKG) yang dikeluarkan Kementerian Pendidikan Nasional Tahun 2010, menjelaskan bahwa dalam konteks pendidikan di Indonesia, penilaian kinerja (performance appraisal), lebih difokuskan pada individu.

Penilaian Kinerja Guru (PKG) dimaksudkan untuk mengidentifikasi kemampuan seorang guru dalam memanfaatkan pengetahuan, keterampilan, dan kompetensi yang dibutuhkan sebagaimana diamanatkan dalam Peraturan Menteri Pendidikan Nasional Nomor 16 Tahun 2007 tentang Standar Kualifikasi Akademik dan Kompetensi Guru untuk melaksanakan pekerjaannya sebagai guru, sesuai dengan rincian tugas guru. Pengetahuan, Keterampilan, dan penguasaan kompetensi tersebut sangat menentukan tercapainya kualitas proses pembelajaran bagi peserta didik

\section{d. Supervisi Kepala Sekolah}

Supervisi adalah serangkaian kegiatan membantu guru mengembangkan kemampuannya memgelola proses pembelajaran untuk mencapai tujuan pembelajaran (Daresh,1989) dan (Glickman 2007). Supervisi Akademik berhubungan dengan Penilaian Kinerja Guru dalam mengelola pembelajaran. Supervisi Akademik terkait langsung keberhasilan peserta didik dalam belajar. Tujuan supervisi yaitu membantu guru mengembangkan kompetensinya, mengembangkan kurikulum, mengembangkan kelompok kerja guru, membimbing penelitian tindakan kelas (Glickman,2007 dan Segiovani,1987).

Pelaksanaan supervisi pembelajaran merupakan tugas kepala sekolah sebagai supervisor tingkat sekolah. Dipertegas oleh Permendiknas Nomor 13 tahun 2007 tentang Standar Kepala Sekolah/ Madrasah bahwa Supervisi Akademik memang harus dilakukan oleh kepala sekolah. Purwanto (2012), mengemukakkan bahwa salah satu fungsi kepala sekolah adalah sebagai supervisor pengajaran salah satunya membimbing guru dalam menyusun program semester program satuan pelajaran. Suharsimi(2006) menyampaikan pengertian supervisi pembelajaran yang menitikberatkan pengamatan pada masalah pembelajaran langsung berada dalam lingkup kegiatan pembelajaran yang dilakukan oleh guru untuk membantu peserta didik ketika sedang dalam proses belajar. Jika kualitas pembelajaran meningkat akan berdampak juga pada peningkatan prestasi belajar peserta didik dan berdampak juga pada kualitas lulusan sekolah itu. 
Senada dengan Jones dan Mulyasa, (2000) mengemukakan bahwa supervisi adalah usaha dari petugas-petugas sekolah dalam memimpin guru-guru dan petugas-petugas lainnya dalam memperbaiki pengajaran, termasuk menstimulasi, menyeleksi pertumbuhan jabatan dan perkembangan guru-guru serta merevisi tujuan-tujuan pendidikan, bahan pengajaran dan metode serta evaluasi pengajaran. Supervisi adalah aktivitas menentukan kondisi/syaratsyarat yang essensial yang akan menjamin tercapainya tujuan-tujuan pendidikan. Dari definisi tersebut maka tugas kepala sekolah sebagai supervisor berarti bahwa dia hendaknya pandai meneliti, mencari, dan menentukan syarat-syarat mana sajakah yang diperlukan bagi kemajuan sekolahnya sehingga tujuan-tujuan pendidikan di sekolah itu semaksimal mungkin dapat tercapai.

Jadi supervisi kepala sekolah merupakan upaya kepala sekolah dalam mengawasi dan membina guru agar dapat meningkatkan kualitas pembelajaran melalui langkah-langkah perencanaan program supervisi, pelaksanaan program supervisi, monitoring dan evaluasi, tindak lanjut hasil supervisi, penampilan mengajar yang nyata serta mengadakan perubahan yang rasional untuk meningkatkan hasil belajar siswa.

\section{e. Motivasi Kerja}

Motivasi merupakan daya gerak yang menciptakan kegahirahan kerja seseorang agar mau bekerjasama, bekerja efektif dan terintregasi dengan segala upayanya untuk mencapai kepuasan. Motivasi juga diartikan sebagai upaya peggerak dari dalam dan dari luar subyek untuk melakukan akifitas-aktifitas tertentu demi mencapai tujuan dan kemamuan untuk menggerakkan upaya yang besar kearah pencapaian tujuan organisasi, yang dikondisikan oleh kemampuan upaya untuk memuaskan sejumlah kebutuhan individu.

Istilah motivasi merujuk pada dasar yang mendorong tindakan. Satu perangkat teori menganggap kekurangan kebutuhan sebagai kondisi pendorong yang menimbulkan presdiposisi tertentu. Sementara teori lain menganggap harapan dalam lingkungan menimbulkan tujuan tertentu. Berikut adalah beberapa teori yang menjelaskan tentang bagaimana kebutuhan

\section{f. Budaya Organisasional}

Secara komprehensif budaya organisasi sekolah didefinisikan sebagai sebuah corak dan asumsi-asumsi dasar-ditemukan, atau dikembangkan oleh sebuah kelompok tertentu untuk belajar mengatasi problem-problem kelompok dari adaptasi eksternal dan integral internal yang telah bekerja dengan baik, cukup relevan untuk dipertimbangkan sebagai sesuatu yang yang benar untuk berpersepsi, berpikir dan berperasaan dalam hubungannya dengan problem-problem tersebut (Schein, 1991). Definisi tersebut diatas terlalu kompleks (Robbins,2011) budaya organisasi merupakan sistem makna bersama yang dianut oleh anggotaanggota yang membedakan organisasi itu dari organisasi-organisasi lain.

Tampubolon (2003) menyimpulkan budaya sekolah adalah merupakan kesepakatan perilaku guru di dalam sekolah yang digambarkan dengan selalu berusaha menciptakan efisiensi, bebas dari kesalahan, perhatian terfokus kepada hasil dan kepentingan guru, kreatif dan akurat menjalankan tugas.

\section{g. Konsep Moderasi}

Ghozali dalam Sunarto (2008) menyatakan bahwa variabel pemoderasi (moderating) adalah variabel independen yang akan menguatkan atau melemahkan hubungan antara variabel independen lainnya terhadap variabel dependen. Pendapat lain mengenai penelitian eksplanatori (Explanatory Research) dengan Moderation Regression Analisys, Baron dan Kenny mendefinisikan moderator sebagai "variabel kualitatif atau kuantitatif yang mempengaruhi arah dan/ atau kekuatan hubungan antara variabel independen dan dependen atau kriteria" (Sauer, 1993). Variabel moderasi ada dua: (a) Quasi moderator adalah jika variabel moderator baik berinteraksi dengan variabel prediktor (dependen) dan secara langsung berkaitan dengan variabel kriteria; dan (b) Pure moderation adalah jika variabel moderator.

\section{h. Perumusan Hipotesis}

1) Apakah Supervisi Kepala Sekolah berpengaruh terhadap Kinerja Guru?

2) Apakah Motivasi berpengaruh terhadap Kinerja Guru?

3) Apakah Budaya Organisasional berpengaruh terhadap Kinerja Guru?

4) Apakah Budaya Organisasional Memoderasi Pengaruh Motivasi terhadap Kinerja Guru?

\section{Model Matematik}

$Y=a+\beta_{1} X_{1}+\beta_{2} X_{2}+\beta_{3} Z+\beta_{4}\left|X_{1}-Z\right|+\beta_{5}\left|X_{2}-Z\right|+e$

Dimana :

$\mathrm{Y}$ = Kinerja Guru (Variabel dependen)

$\mathrm{a}=$ Konstant

$\mathrm{X} 1=$ Supervisi KS (variabel independen)

$\mathrm{X} 2$ = Motivasi Kerja (variabel independen)

$\mathrm{Z}$ = Budaya Organisasional (Variabel moderat)

$ß 1$ = Besaran pengaruh supervisi KS (X1) terhadap kinerja guru ( $\mathrm{Y}$ )

$\beta_{2}=$ Besaran pengaruh motivasi kerja $\left(X_{2}\right)$ terhadap kinerja guru $(\mathrm{Y})$

$\beta_{3}=$ Besaran pengaruh budaya organisasional (Z) terhad kinerja guru (Y) 
$\beta_{4}=$ Besaran pengaruh Supervisi KS $\left(\mathrm{X}_{1}\right)$ terhadap kinerja gutu $(\mathrm{Y})$ dimoderasi Budaya organisasional (Z)

$\beta_{5}=$ Besaran pengaruh motivasi kerja $\left(X_{2}\right)$ terhadap kinerja guru $(\mathrm{Y})$ dimoderasi Budaya organisasional (Z)

Moderat_1 $=|\mathrm{X} 1-\mathrm{Z}|$

Moderat_2 = $\left|\mathrm{X}_{2}-\mathrm{Z}\right|$

$\mathrm{e}=$ Error, yaitu variabel lain yang tidak masuk dalam model,tetapi mempengaruhi kinerja guru.

\section{METODE PENELITIAN}

Penelitian ini merupakan penelitian eksplanatori (Explanatory Research) yang akan membuktikan hubungan kausal antara variabel bebas (Independent Variable) yaitu variabel supervisi kepala sekolah (X1) dan variabel motivasi (X2), variabel moderasi (Moderating Variable) yaitu variabel budaya organisasi (Z) serta variabel terikat (Dependent Variable) yaitu variabel kinerja guru (Y).

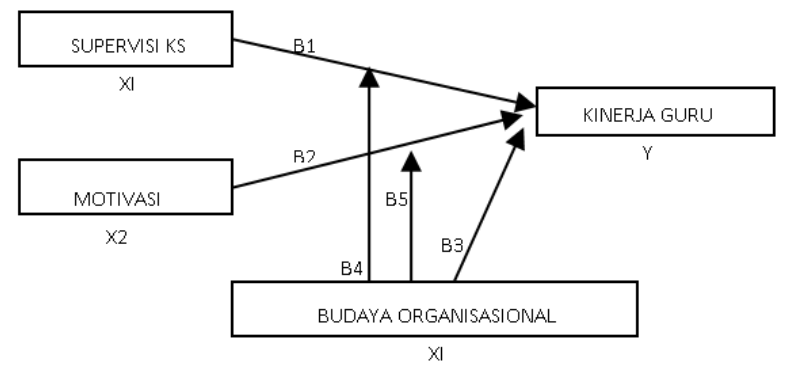

Gambar 1. Model Empiris dalam Penelitian

Model Empiris yag digambarkan diatas untuk mengetahui Pengaruh Supervisi Kepala Sekolah dan Motivasi terhadap Kinerja Guru Dimoderasi Budaya Organisasional

\section{HASIL DAN PEMBAHASAN}

\section{A. Hasil Penelitian}

\section{Uji Validitas}

Uji validitas menunjukkan sejauh mana ketepatan dan kecermatan suatu alat ukur dapat mengukur suatu konstruk. Uji validitas dilakukan menggunakan analisis faktor. Suatu kuesioner dikatakan valid, jika pertanyaan pada kuesioner mampu mengungkapkan suatu yang akan diukur oleh kuesioner tersebut (Gozali, 2005). Apabila nilai KMO diatas 0,50 maka sampel dalam penelitian dianggap sudah mencukupi dan layak untuk dianalisis lebih lanjut. Loading Factor (component matrix) nilainya lebih dari 0,4 maka valid dan layak untuk dianalisa lebih lanjut.

\section{Uji Reliabilitas}

Pengujian ini perlu dilakukan untuk mengetahui sejauh mana suatu alat ukur dapat dipercaya dan dapat diandalkan. Reliabilitas adalah sebuah analisis yang menunjukkan tingkat kemantapan dan ketepatan suatu alat ukur, yaitu dalam arti apakah ukuran yang diperoleh merupakan ukuran yang benar dari sesuatu yang diukur. Tujuan pengujian ini adalah untuk mengetahui sejauh mana pengukuran dapat memberikan hasil yang konsisten bila dilakukan pengukuran kembali terhadap obyek/responden yang berbeda. Data yang diuji reliabilitasnya adalah data yang telah lulus dalam pengujian validitas dan hanya penyataan-pernyataan yang valid saja yang diuji. Uji reliabilitasnya dalam penelitian ini menggunakan nilai alpha cronbach 0,7 dimana suatu alat ukur dinyatakan semakin reliabel apabila hasil dari perhitungan alpha cronbach diatas 0,7 . Hasil pengujian data yang sudah dilakukan terlihat nilai alpha dari masingmasing variabel diatas angka 0,7. Adapun alpha $(\alpha)$ untuk tiap variabel pernyataan (kuesioner) dalam penelitian ini.

\section{Uji Normalitas}

Hasil uji normalitas error (residual) pada tabel 4.18 menunjukkan besaran Asymp.sig pada uji Kolmogorov-smirnov Z adalah 0,973 karena lebih besar dari 0,05 . Perolehan angka yang nonsignifikan tersebut berarti normalitas error (residual) terpenuhi.

persamaan moderasi tipe quasi teknik selisih mutlak:

$Y=a+\beta_{1} X_{1}+\beta_{2} X_{2}+\beta_{3} Z+\beta_{4}\left|X_{1}-Z\right|+\beta_{5}\left|X_{2}-Z\right|+e$ $Y=0,159 X_{1}+0,096 X_{2}+0,588 Z-0,187 \mid X_{1}-$

$\mathrm{Z}|+0,088| \mathrm{X}_{2}-\mathrm{Z} \mid$

Hasil olahan data menunjukan bahwa: (1) supervisi KS tidak berpengaruh positif dan tidak signifikan terhadap kinerja guru $(B=0,159$ sig=0,108), (2) Motivasi kerja tidak berpengaruh terhadap Kinerja Guru $(\beta=0,96$ sig=0,313), (3) Budaya Organisasional berpengaruh positif dan signifikan terhadap Kinerja Guru $(ß=0,588$ sig $=0,000)$, (4) Budaya Organisasional memperkuat pengaruh Supervisi terhadap kinerja guru $(ß=0,187$ sig $=0,045)$,dan (5) Budaya Organisasional tidak memoderasi pengaruh Motifasi Kerja terhadap Kinerja guru $(B=0,88$ sig $=0,276$ ).

\section{Uji Heteroskedastisitas}

Hasil uji heteroskedastisitas (Glejzer) pada tabel 4.20 menunjukkan nilai signifikansi pada variabel Supervisi (X1) sebesar 0,372, Motivasi sebesar 0,237, Budaya organisasional sebesar 0,060; Selisih mutlak mutlak Supervisi dan budaya organsasonal sebesar 0,826; Selisih mutlak motivasi dan budaya organisasonal sebesar 0,078 ,semuanya menpunyai nilai lebih besar dari 0,05 sehingga tidak terjadi Heteroskedastisitas. 


\section{Pengujian Model}

Setelah dilakukan pengujian Validitas, Reliabilitas, dan Asumsi Klasik, langkah selanjutnya adalah memformulasikan persamaan Regresi. Sesuai dengan rumusan dalam bab sebelumnya bahwa uji model merupakan suatu analisis yang sering digunakan dalam memprediksi seberapa besar pengaruh variabel independen terhadap variabel dependennya.

\section{Uji Determinasi $\left(R^{2}\right)$}

Hasil uji determinasi (R2) pada tabel 4.21 menunjukkan nilai adjusted $\mathrm{R}$ square sebesar 0,471 artinya $47,1 \%$ perubahan dari variabel kinerja guru dapat dijelaskan oleh variabel supervisi,motivasi kerja,budaya organisasional serta hasil moderasi_1 dan moderasi_2.

\section{Uji F (Goodness of Fit)}

Hasil uji F (goodness of fit) pada tabel 4.22 menunjukkan nilai F 22,213 (sig.0,000). Dari hasil uji tersebut menunjukkan tingkat signifikansinya 0,000 atau $<0,05$, maka dapat disimpulkan model yang digunakan memenuhi persyaratan Goodness of Fit.

\section{Pengujian Hipotesis}

Pengujian hipotesis pada model regresi moderasi dilakukan dengan dua cara, yaitu: Uji t(signifikansi).Jika nilai sig $<0,05$ maka dinyatakan hipotesis diterima,apabila nilai sig $>0,05$ maka hipotesis ditolak.

Uji regresi signifikansi pada penelitian dilakukan untuk mengetahui signifikansi dan arah pengaruh variabel dependen terhadap variabel depen pada pengajuan 5 (lima) hipotesis pada bab sebelumnya.

\begin{tabular}{|c|c|c|c|c|c|c|}
\hline \multirow{2}{*}{\multicolumn{2}{|c|}{ Moco: }} & \multicolumn{2}{|c|}{ Vesizaterdisgd Coofficioath } & \multirow{3}{*}{ 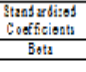 } & \multirow[b]{3}{*}{6.197} & \multirow{3}{*}{$\frac{\text { Sif: }}{0.00}$} \\
\hline & & 3 & Sis oryor & & & \\
\hline \multirow{6}{*}{1} & \begin{tabular}{|l|l}
$(C 5 s i z a t)$ \\
\end{tabular} & 1.576 & .177 & & & \\
\hline & Sop syisi & .081 & .052 & 159 & 1,620 & .108 \\
\hline & 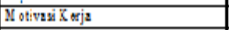 & .076 & .075 & .096 & 1,014 &., 133 \\
\hline & \begin{tabular}{|l|l} 
Bud yzz orgairsuosa: \\
\end{tabular} & .459 & .068 & 583 & 6,715 & .000 \\
\hline & 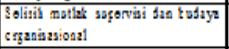 & 134 & . 066 & ,18? & 2,027 & .045 \\
\hline & 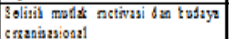 & .113 & .104 & .088 & 1,695 & .276 \\
\hline
\end{tabular}

moderasi, hipotesis 1 (H1) dinyatakan ditolak; mengandung makna bahwa supervisi kepala sekolah tidak berpengaruh positif dan signifikan terhadap kinerja guru. Berdasarkan deskriptif variabel, kondisi empiris ini terjadi karena sebagian guru masih menganggap supervisi kepala sekolah adalah formalisasi kewenangan saja. Kepala Sekolah memang belum mampu menjalankan fungsi Supervisi dengan optimal. Bahkan pada beberapa sekolah yang memiliki guru-guru senior dalam kategori masa kerja, mereka cenderung kurang menerima kepala sekolah muda yang melakukan supervisi. Menurut Purwanto (2005) ada beberapa faktor yang mempengaruhi berhasil tidaknya supervisi atau cepat-lambatnya hasil supervisi antara lain: (1) lingkungan masyarakat tempat sekolah itu berada; (2) besar-kecilnya sekolah yang menjadi tanggung jawab kepala sekolah;(3) tingkatan dan jenis sekolah; (4) keadaan guru-guru dan pegawai yang tersedia; dan (5) kecakapan dan keahlian kepala sekolah itu sendiri. Di antara faktorfaktor yang lain, yang terakhir ini adalah yang terpenting. Bagaimanapun baiknya situasi dan kondisi yang tersedia, jika kepala sekolah itu sendiri tidak mempunyai kecakapan dan keahlian yang diperlukan, semuanya itu tidak akan ada artinya. Penelitian dengan hasil sama juga pernah dilakukan oleh Sidhu (2010).

b) Motivasi kerja berpengaruh positif dan signifikan terhadap kinerja guru

Berdasarkan Tabel hasil analisis regresi, motivasi kerja berpengaruh positif dan sidnifikan terhadap kinerja guru dinyatakan ditolak; mengandung makna bahwa motivasi kerja tidak berpengaruh terhadap kinerja guru. Berdasarkan hasil uji regresi dan deskripsi variabel, kondisi empiris ini terjadi karena sebagian besar responden mempunyai usia $>41$ tahun sehingga mereka tidak ada dorongan yang kuat untuk berprestasi ataupun kemajuan sekolah. Hal ini sesuai dengan hasil penelitian (Mindarti dan Fuad) yang menyatakan bahwa Motivasi tidak berpengaruh positif terhadap kinerja Guru.

\section{c) Budaya organissional berpengaruh positif dan signifikan terhadap kinerja guru \\ Berdasarkan hasil pengujian pada} Hipotesis 3 (H3) dinyatakan diterima; mengandung makna bahwa Budaya Organisasional berpengaruh positif dan signifikan terhadap Kinerja Guru. Selain hasil uji regresi yang sudah dijelaskan pada subbab sebelumnya, salah satu faktor yang menjadi alasan hipotesis ini diterima adalah sebagian besar responden berasepsi baik terhadap Budaya Organisasional.

Berdasarkan hasil uji regresi dan deskriptif variabel, kondisi empiris ini terjadi karena sebagian besar guru menganggap bahwa Budaya Sekolah yang efektif sangat dibutuhkan untuk membiasakan Guru dalam rangka meningkatkan kinerjanya. Budaya sekolah adalah salah satu faktor yang mempengaruhi proses kinerja, seperti halnya pola keguruan, rentang kendali, gaya kepemimpinan dan teknologi. Perilaku dan kinerja sangat dipengaruhi oleh faktor ini. Konsep Budaya organisasi sesuai pendapat Miller (1987). Budaya sekolah adalah pola yang ditemukan atau dikembangkan oleh sekelompok sekolah dalam hubungannya 
dengan masalah - masalah sekolah berkaitan dengan dua nilai Primer (nilai keunggulan, nilai kesatuan, nilai imbalan berdasarkan prestasi, nilai empiris, nilai keakraban dan nilai integritas) dan nilai sekunder (nilai berfokus pada pelayanan,nilai pengendalian yang disiplin,nilai kemandirian,nilai pengambilan keputusan yang tepat,nilai pengendalian strategis dan nilai teknologi unggul).

Hal ini sesuai dengan hasil penelitian (Hutabarat, 2015; Arifin, 2014), sedangkan pendapat Robbins (2011) yang menyatakan bahwa budaya organisasional adalah persamaan persepsi yang dipegang oleh anggota organisasi dalam memberikan arti penting karena masing-masing anggota mempunyai latar belakang dan level yang berbeda. Penelitian dengan hasil sama juga pernah dilakukan oleh Zebedeus (2008), Arifin (2015), Nurlaili (2013), dan Hutabarat (2015).

\section{d) Budaya orgnisasional memoderasi pengaruh supervisi Kepala sekolah dengan kinerja guru}

Berdasarkan hasil pengujian pada hipotesis 4 (H4) dinyatakan diterima mengandung makna bahwa Budaya Organisasional memperkuat pengaruh Supervisi Kepala Sekolah terhadap kinerja guru. Selain hasil uji regresi yang sudah dijelaskan pada subbab sebelumnya, salah satu faktor yang menjadi alasan hipotesis ini diterima adalah sebagian besar responden berpersepsi baik terhadap Budaya Organisasional, tetapi berpersepsi kurang baik terhadap Supervisi. Supervisi Kepala Sekolah yang semula pada Hipotesis 1 (H1) tidak berpengaruh terhadap kinerja guru, setelah berinteraksi dengan Budaya Organisasional, Budaya organisasi memperkuat pengaruh Supervisi Kepala Sekolah terhadap Kinerja guru.

Berdasarkan hasil uji regresi dan deskriptif variabel, kondisi empiris ini terjadi karena sebagian besar guru menganggap bahwa Budaya Orgasinisasional dapat memp erkuat pengaruh Supervisi Kepala Sekolah terhadap Kinerja Guru secara berkelanjutan. Hal tersebut sesuai dengan teori yang dikemukakan oleh Robbins (2009) yang menyatakan bahwa Budaya Organisasional adalah persamaan persepsi yang dipegang oleh anggota organisasi dalam memberikan arti penting karena masing-masing anggota mempunyai latar belakang dan level yang berbeda.

\section{B. Pembahasan}

Pada sub-bab ini disajikan pembahasan mengenai hasil uji moderasi pada variabelvariabel independen terhadap variabel dependennya. Sesuai dengan konsep pemoderasi (moderating) dinyatakan bahwa variabel moderating adalah variabel independen yang akan menguatkan atau melemahkan hubungan antara variabel independen lainnya terhadap variabel dependen (Ghozali dalam Sunarto, 2008).

Hasil Uji regresi moderasi, hipotesis 1 (H1) dinyatakan ditolak; mengandung makna bahwa supervisi kepala sekolah tidak berpengaruh positif dan signifikan terhadap kinerja guru. Pada uji hipotesis 2 (H2) memiliki hasil analisis regresi, motivasi kerja berpengaruh positif dan sidnifikan terhadap kinerja guru dinyatakan ditolak; mengandung makna bahwa motivasi kerja tidak berpengaruh terhadap kinerja guru, sedangkan pada hasil uji regresi Hipotesis 3 (H3) memiliki hasil dinyatakan diterima; mengandung makna bahwa Budaya Organisasional berpengaruh positif dan signifikan terhadap Kinerja Guru. Selain hasil uji regresi yang sudah dijelaskan pada subbab sebelumnya, salah satu faktor yang menjadi alasan hipotesis ini diterima adalah sebagian besar responden berasepsi baik terhadap Budaya Organisasional. Dan pada hasil uji hipotesis 4 (H4) dinyatakan diterima mengandung makna bahwa Budaya Organisasional memperkuat pengaruh Supervisi Kepala Sekolah terhadap kinerja guru.

\section{SIMPULAN DAN SARAN}

\section{A. Simpulan}

berdasarkan hasil pengujian instrumen dan regresi moderasi yang telah dilakukan sebelumnya, maka dapat disimpulkan beberapa hal sebagai berikut:

1) Kinerja Guru tidak dipengaruhi oleh Supervisi Kepala Sekolah, artinya tinggi rendahnya Supervisi Kepala Sekolah tidak mempengaruhi kinerjanya, tetapi Budaya Sekolah dapat memperkuat pengaruh Supervisi Kepala Sekolah terhadap Kinerja Guru.

2) Kinerja Guru tidak dipengaruhi oleh Motivasi, artinya tinggi rendahnya Motivasi Guru dapat tidak mempengaruhi kinerjanya, tidak memoderasi pengaruh Motivasi terhadap Kinerja Guru.

Adapun Keterbatasan penelitian antara lain pada hasil uji koefisien determinasi ((Adjusted $\mathrm{R}$ Square) dengan nilai 0,471 yang artinya hanya $47,1 \%$ kemampuan variabel independen (Supervisi kepala sekolah, Motivasi kerja,budaya organisasional serta hasil moderasi_1 dan moderas_2), sedangkan sisanya sebesar ( $100 \%$ $47,1 \%$ ) yaitu $0,52,9 \%$ dipengaruhi oleh variabel lain diluar penelitian. 


\section{B. Saran}

Berdasarkan hasil penelitian mengenai peran budaya organisasional memoderasi pengaruh komitmen organisasional dan motivasi kerja terhadap kinerja guru pada SMK Negeri I Ampelgading di Kabupaten Pemalang, maka kami sarankan hal-hal sebagai berikut:

1) Kepala Sekolah perlu meingkatkan motivasi kerja kepada masing-masing guru sehingga dapat meningkatkan kinerja guru.

2) Bagi peneliti yang akan datang terbuka peluang untuk mengembangkan model yang lebih baik dengan memasukan atu menmbah variabel- variabel yang memiliki kemungkinan dapat dijadikan prekdiktor yang lebih baik terhadap kinerja guru selain variabelvariabel bebas yang telah dikembangkan dalam penelitian ini, dan juga dapat dilakukan model perdimensi.

\section{DAFTAR RUJUKAN}

Ali, Muhammad. 1988. Metode Penelitian Kependidikan. Jakarta : Rineka Cipta

Algifari. 1997. Analisis Regresi, Kasus dan Solusi. Yogyakarta :BPFE

Anoraga, Pandji. 1998.Psikologi Kerja. Jakarta :Rineka Cipta

Arikunto, Suharsimi, 1998. Prosedur Penelitian Suatu Praktek. Jakarta : Rajawali Press

As'ad, Moh. 1995. Psikologi Industri. Liberty: Yogyakarta.

Gurnam, Kaur, Sidhu, dan Chan, Yuen, Fook. 2010 Formatif Supervision of Teaching and Learning : Issues and Concerns for the school Head Journal of Scientific Research, 4 : $589-605$.

Hasibuan, Malayu SP. 1999. Organisasi dan Motivasi. Jakarta : Bumi Aksara

Handoko, Hani. 1995. Manajemen Personalia dan Sumber Daya Manusia. Yogyakarta:BPFE. 2000. Manajemen Sumber Daya Manusia. Jakarta : Bumi Aksara

Hikmawati, Afni. 2005. Pengaruh Kepemimpinan Kepala Sekolah, Motivasi Kerja dan Disiplin Kerja Terhadap Kinerja Guru pada SMK Negeri di Wonosobo. Tesis tidak dipublikasikan. Semarang: Program Pasca Sarjana Universitas Negeri Semarang.

Manulang. 2001. Manajemen Personalia. Yogyakarta: Gadjah Mada University Press

Miller, L.M. 1992. Manajemen Era Baru : Beberapa Pandangan Mengenai Budaya Perusahaan Modern. Jakarta : Erlangga.

Mulyasa, E. 2004. Menjadi Kepala Sekolah Profesional. Bandung: Remaja Rosdakarya
Pidarta, Made. 1996. Pemikiran tentang Supervisi Pendidikan. Jakarta : Bumi Aksara

Purwanto, M. Ngalim. 2004. Administrasi dan Supervisi Pendidikan. Bandung: Remaja Rosdakarya

Rachman, Maman. 2004. Konsep dan Analisis Statistik. UPT Penerbitan \& Percetakan Unnes Press. Semarang.

Rahayu, Sri retno Pudji. 2005. Pengaruh Persepsi Gaya Kepemimpinan Kepala Sekolah dan Motivasi terhadap Kinerja Guru SMK Negeri Bisnis Manajemen di kota Semarang. Semarang: Program Pasca Sarjana Universitas Negeri Semarang.

Remedies.Richard \& Nick Boreham. 2002. Organisasional learning and employe' instrisik motivation."Journal organization Learning and Instrinsic Motivation.

Riduwan.2010. Skala Pengukuran Variable-Variable Penelitian. Alfabeta: Bandung

Robbins, Stephen P. 2009. Organizational Behavior Edition 13. Pearson Prentice Hall Pearson Education Internasional.

Ruvendi, Ramlan. 2005. Imbalan dan Gaya Kepemimpinan Pengaruhnya terhadap Kepuasan Kerja Karyawan di Balai Besar Industri Pertanian Bogor.Tesis.UNS Solo.

Sahertian, Piet A. 2000. Konsep-Konsep dan Teknik Supervisi Pendidikan Dalam Rangka Pengembangan Sumber Daya Manusia. Jakarta: Rineka Cipta.

Sampurnaningsih, S. R., Andriani, J., Zainudin, Z. A. B. A., \& Sunarsi, D. (2020). The Analysis of Entrepreneurship Character and Entrepreneurship Intention among Students. PalArch's Journal of Archaeology of Egypt/Egyptology, 17(6), 8290-8303.

Schein. 1991. Budaya organisasi Edisi Ke enam . PT. Prenhallindo. Jakarta.

Sobarna, A., Sunarsi, D., \& Roinadi, D. K. (2020). The Effect of Pedagogic Competence Kids Athletic toward Motivation for Elementary School. Solid State Technology, 63(6), 1364-1371.

Sulistyorini. 2009. Model Pembelajaran Salingtemas. Unnes Semarang.

Sunarno, Agus. 2005. Pengaruh Motivasi Kerja. Kepemimpinan Kepala Sekolah dan Lingkungan Kerja terhadap Kinerja Guru.Tesis.Unnes.

Sunarsi, D. (2020). Panduan Meningkatkan Kinerja Dan Kepuasan Guru. Kota Serang: Desanta Muliavisitama

Sunarto.2008. Peran Persistensi Laba Memperlemah Hubungan Antara Earnings Opacity dengan Cost 
of Equity dan trading Volume Activity.Studi Empiris pada Perusahaan Go Public di Indonesia selain Sektor Keuangan dan Properti. Disertasi. Undip Semarang.

Supandi. 1996. Administrasi dan Supervisi Pendidikan. Jakarta: Departemen Agama

Supriadi, Dedi. 1999. Mengangkat Citra dan Martabat Guru. Yogyakarta: Adicita Karya Nusa.

Usman, Moh Uzer. 2000. Menjadi Guru Profesional. Bandung: Remaja Rosdakarya
Wardana, Wisnu, L. 2008. Analisis pengaruh motivasi kerja,Disiplin Kerja, Pendidikan dan pelatihan terhadap Kinerja Guru SD di Keamatan Gayungan kota Surabaya."Jurnal Ekonomi managemen dan Bisnis,Vol.11,No 1,April, UNIMAS Mojokerto.

Wardani, IGK. 1996. Alat Penilaian Kemampuan Guru (APKG). Jakarta: Dirjen Pengendalian Mutu Pendidik dan Tenaga Kependidikan

Yuangga, K. D., \& Sunarsi, D. (2018). The Influence of Procrastination and Low Time Management on Student Self Efficacy (at MA Soebono Mantofani). PINISI Discretion Review, 2(1), 85-92. 